\title{
CURRICULUM IMPLEMENTATION PLANNING ON THE TACTICAL ASSEMBLY OF DINIYAH CONVERSION (MTKD) IN THE CITY OF BANDUNG
}

\author{
Yustina Yuliasari \\ STAI Yamisa Soreang \\ Email: yuliasefter@gmail.com
}

\begin{abstract}
The curriculum as an educational design has a fairly central position in all educational activities, determining the implementation process and educational outcomes. Given the important role of the curriculum in education and in the development of human life, curriculum preparation cannot be done carelessly. Sukmadinata emphasized that curriculum preparation requires strong foundations, which are based on the results of in-depth thought and research. Planning for curriculum implementation is carried out by compiling a curriculum that is tailored to the needs and level of knowledge of the congregation, then determining the curriculum concept to be applied, the methods to be used and the learning strategies to be implemented. The curriculum team compiles learning materials and divides learning materials into semester, monthly and material in each meeting.
\end{abstract}

Keywords : Curriculum, Educational Activities, Implementation

\section{A. INTRODUCTION}

The curriculum is one of the most important factors in the educational process. Every educational institution in the form of formal, informal and non-formal education requires a curriculum as an educational plan to be instilled in students.

According to Sukmadinata, curriculum is all aspects related to education such as learning methods and learning objectives. Meanwhile Hidayat explores the meaning of curriculum further, according to him, curriculum has several meanings, namely: (1) as a learning plan, (2) as a student learning plan, (3) as a learning experience obtained by students from schools or madrasah (Sukmadinata, 2012. p. 4).

Meanwhile, Arifin argued that the curriculum is all learning activities and experiences as well as "everything" that affects the personal formation of students, both at school and outside of school for the responsibility of the school to achieve educational goals. Everything that is meant here is a hidden curriculum, for example school facilities, a safe environment, an atmosphere of intimacy, harmonious cooperation and so on which are considered to support the success of education. (Arifin, 2013. p. 5). Dewey as quoted by Ornstein and Hunkins argues that: "curriculum is all the experiences children have under the guidance of teachers" (Ornstein \& Francis, 2009. p. 10). 
The curriculum is a written plan about the abilities that must be possessed based on national standards, materials that need to be studied and learning experiences that must be undertaken to achieve these abilities and evaluations that need to achieve the abilities of students, as well as a set of regulations relating to the learning experience of students in developing their potential. on units (Hamalik, 2006. p. 91).

Sanjaya emphasized that the curriculum as a plan with curriculum formulation according to the education law which is used as a reference in the implementation of the education system, namely law number 20 of 2003 concerning the national education system, defines curriculum as a set of plans and arrangements regarding objectives, contents, and materials as well as which procedures are used as guidelines for implementing learning activities to achieve certain educational goals (Sanjaya, 2005. p. 4).

The curriculum as an educational design has a fairly central position in all educational activities, determining the implementation process and educational outcomes. Given the important role of the curriculum in education and in the development of human life, curriculum preparation cannot be done carelessly. Sukmadinata emphasized that curriculum preparation requires strong foundations, which are based on the results of in-depth thought and research. If the foundation for the construction of a building is not solid, it is the building that will collapse, but if the foundation for education, especially the curriculum is weak, it is the people who will collapse (Sukmadinata, 2012. p. 38).

In order to increase the role of majelis taklim as a non-formal Islamic education institution for the community, the Ministry of Religion of Bandung City through the Extension Working Group (Pokjaluh) initiated a concept of developing the Taklim Council by forming the Diniyah Conversion Taklim Council (MTKD).

The Diniyah Conversion Taklim Council (MTKD) is a model for the development of majelsi taklim which in the implementation of learning converts the madrasah diniyah curriculum. If in general the activities of majelis taklim are carried out conventionally, namely the jama'ah come and then listen to lectures from the ustadz without a structured curriculum and no evaluation, then the Diniyah Conversion Majelsi (MTKD) learning is carried out in a structured manner starting from the subject structure to evaluation.

The model for developing majelis taklim as applied by the Diniyah Conversion Taklim Council (MTKD) is a new phenomenon in the implementation of majelis taklim. In general, the majelis taklim assembly is carried out conventionally, namely the congregation comes to the taklim assembly to get religious lectures from the ustadz. The lecture material delivered is generally unstructured but more thematic in nature, there is no lesson schedule and also the congregation is not burdened by the evaluation. 
The results of the author's preliminary study found that the Diniyah Conversion Taklim Council (MTKD) was a taklim council whose management was converting from Madrasah Diniyah. Like Madarasah Diniyah Takmiliyah, the Diniyah Conversion Taklim Council (MTKD) is implemented in a structured and tiered manner and has a curriculum. Drs. K.H. Asep Totoh Gozali, M.Ag (Director of MTKD Bandung City / Islamic Religion Extension Ministry of Religion Bandung City). said that learning at MTKD is carried out by referring to the curriculum that has been prepared by the curriculum team, both objectives, materials, methods and learning evaluation. The content of the subject matter in the MTKD curriculum consists of Al-Qur'an, Hadith, Jurisprudence, Morals and Date / History.

One of the problems that arise in the implementation of the Diniyah Conversion Taklim Council (MTKD) is in the implementation of the curriculum. This is because the MTKD participants are not teenagers but parents whose average age is over 50 years. In addition, the paradigm of majelis taklim which only comes to listen to lectures without having to be burdened by attendance and evaluation is also still inherent in some MTKD participants.

In addition, in the implementation of learning at the Diniyah Conversion Taklim Council (MTKD) also implements a directed goal not only for the congregation to know religious knowledge and be able to practice what is conveyed by ustadz, but graduates from MTKD are required to be able to teach what they have learn from the congregation in each majelis taklim.

The implementation of majelis taklim with the madrasah diniyah conversion system which requires a curriculum that includes subject structure, learning planning and learning evaluation is a new phenomenon so that the authors consider it important to conduct indepth research to find out how the curriculum is implemented in majelis taklim.

Implementation of the curriculum is the actualization of the curriculum in the form of learning. Curriculum implementation can be defined as a process of applying ideas, concepts, and curriculum policies (potential curriculum) in a learning activity so that students master a certain set of competencies, as a result of interaction with the environment.

Fullan defines curriculum implementation as: "Putting into practice of an idea, program or set of activities which is new to the individual or organization using it” (Fullan, 2007. p. 84). 
THINKING FRAMEWORK IMPLEMENTATION OF THE CURRICULUM ASSEMBLY OF EARLY CONVERSION

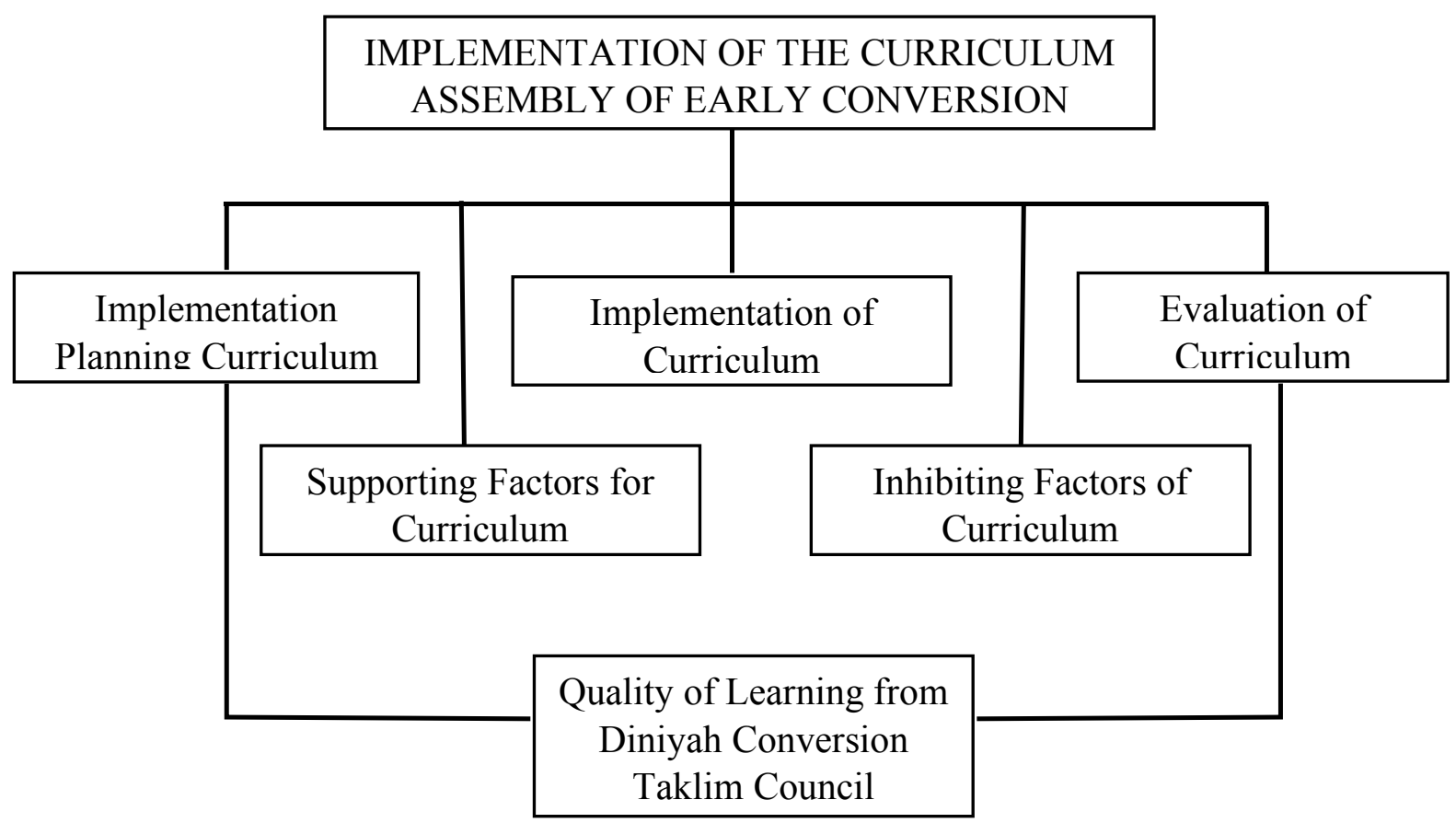

\section{B. METHOD}

The research method used in this research is descriptive qualitative method. The approach used in this research is a systems approach. The factors studied from this approach include the components of the curriculum implementation system, namely: planning, implementation, evaluation, what are the supporting and inhibiting factors in curriculum implementation, as well as seeing the extent of the successful implementation of the curriculum in the Diniyah Conversion Taklim Council (MTKD). throughout the city of Bandung.

\section{RESULTS AND DISCUSSION}

Planning the curriculum of the Diniyah Conversion Council (MTKD) in

\section{Bandung}

To understand more clearly, Islamic education basically demands the presence of a curriculum that is built on the basis of the Islamic concept of how humans relate to God, fellow humans and also their natural environment. So that the MTKD curriculum is an alternative form of Islamic education. The MTKD learning curriculum is a teaching and learning approach in majelis taklim that pays attention to and adjusts to the age level of the congregation / santri who are generally elderly. 
The curriculum is given the connotation of a school effort to influence children so that they can learn well in the classroom, on the school grounds, outside the school environment or all activities to influence the learning subject so that it becomes the expected person. The curriculum is prepared and developed to achieve educational goals, namely to prepare students so that they can live in the community. Prepare students by providing experiences so that they can develop their abilities according to their interests and talents, and have the ability to internalize values in everyday life in accordance with the norms of society. A good curriculum is a curriculum that is sustainable. The curriculum is designed in such a way so that there is no gap that separates the basic education level from the next level of education (Sagala, 2008. p. 1).

The curriculum is a plan designed to smooth the teaching and learning process, both in activities that take place in formal and non-formal institutions (Nasution, 2010. p. 5). In these educational institutions the curriculum is used by educators as a bridge or a very important bridge to reach the end point of a journey to suit educational goals (Hamalik, 2010. p. 16). The curriculum includes the substance of the learning activity plan which is documented in the form of goal formulations, teaching materials, teaching and learning activities, schedules and evaluations (Sukmadinata, 2012. p. 27).

Curriculum planning is a process that involves activities that collect, sort, synthesize and select relevant information from various sources. This information is then used to design and design learning experiences that allow students to achieve learning goals. Beane James defines curriculum planning as a process that involves various elements of participants at many levels making decisions about learning objectives, how to achieve goals, learning situations, examining the effectiveness and meaning of the method (Beane, 1986. p. 32).

Curriculum planning occurs at all levels both teachers, supervisors, administrators and others involved in curriculum efforts. All teachers are involved in planning class-level curriculum. Even at the level (region / region / district), at the national level there must be a representation of teachers. According to Olivia, the curriculum planning level starts from the class level, then individual schools, school districts, state, region, nation and work. Teacher representation must be dominant at the class and department levels (Olivia, 1992. p. 58). Planning an Islamic education curriculum requires a content curriculum that has a further reach, namely not only equipping students with a set of worldly competences (meaning ready to work) only with skills, life skills and other competencies, but also subject matter that equips students to be ready for work. facing a more immortal or eternal life that is facing the presence of Allah SWT. So that the scope of curriculum planning does not only say the world-work, but the world-hereafter.

Hamalik stated that in curriculum planning, the first thing that was put forward was the fact that there was a gap between the strategic ideas and approaches contained in a curriculum and its implementation efforts. This gap is caused by the problem of personal involvement 
in curriculum planning which depends a lot on the curriculum planning approach adopted (Hamalik, 2006. p. 149).

There are two approaches in curriculum planning, namely an "administrative approach" and an approach that is "grass roots approach" (Hamalik, 2006. p. 150). An "administrative approach" to the curriculum was planned by superiors and then passed down to subordinate agencies up to the teachers. So from the top down, from top to bottom at the initiative of the administrators. In this case there is not much that can be done by subordinates in planning curriculum, because the superior has full power in doing the planning. An approach that is grass roots approach, that is, starting from the bottom. This approach emphasizes curriculum planning that involves subordinates even at the teacher level to be able to jointly think of new ideas about the curriculum and be willing to apply them to improve the quality of lessons.

Furthermore, J.G. Owen, quoted by Hamalik, explained that professional curriculum planning must emphasize the problem of how to analyze the conditions that need to be considered as influencing factors in curriculum planning (Hamalik, 2006. p. 151). There are two conditions that need to be considered in curriculum planning, namely:

a) Sociocultural conditions, namely conditions of social interaction that occur in society. This is one of the conditions that need to be considered because basically educational activities are behavioral activities in which there are various social interactions between teachers and students, students and students, and / or teachers and students and their environment.

b) Condition of facilities, this condition is one of the causes of the gap between curriculum planning and curriculum implementers, especially teachers. Facilities that need to be considered, especially are the availability of text books, laboratory equipment, and other practicum tools, funds, facilities and infrastructure as a consideration.

The curriculum as an educational design has a fairly central position in all educational activities, determining the implementation process and educational outcomes. Given the important role of the curriculum in education and in the development of human life, curriculum preparation cannot be done carelessly. Saodih emphasized that curriculum development requires strong foundations, which are based on the results of deep thought and research. If the foundation for the construction of a building is not solid, it is the building that will collapse, but if the foundation for education, especially the curriculum is weak, it is the people who will collapse (Sukmadinata, 2012. p. 38).

The curriculum has two functions, namely the curriculum as a document and the curriculum as implementation. The curriculum as a document serves as a guide for educators and the curriculum as implementation is the realization of the guidelines in the form of learning activities. This learning experience emphasizes the development of motor skills, so that 
graduates have skills and are required. Judging from the aspect of pedagogic competence, the implementation of the curriculum will greatly depend on educators on how to provide learning experiences to their students so that they meet previous competencies. The pedagogical touch in implementing the curriculum will be seen in the ability of educators to develop strategies as knowledge and tips in utilizing all the resources they have and or that can be mobilized to achieve the goals that have been achieved. To carry out the teaching and learning strategy, educators need to have a rich repertoire of methods with various ways of working, while the typical variety of application of a method must be in accordance with certain application backgrounds such as the abilities and habits of educators, availability of equipment and student readiness (Sukmadinata, 2012. p. 5).

Based on the results of the research, it was found that the objective of the preparation of the Diniyah Conversion Taklim Council (MTKD) curriculum was to improve the quality of majelis taklim education, both the quality of learning and the quality of learning outcomes. As for the theoretical and more detailed it consists of four objectives: First, the education given must come from the correct source. Second, education must be beneficial to society. Third, education must be adjusted to the age and needs of the students at each level. Fourth, education must be easily accessed by the santri / congregation participants.

Curriculum goals are divided into three stages, national goals, institutional goals and curricular goals. National goals are goals to be achieved nationally based on the philosophy of the State. Institutional goals are goals that an educational institution wants to achieve as a direct provider of education. Meanwhile, curricular goals are goals to be achieved by a lesson, which are arranged in reference to or based on institutional and national goals.

From several research findings it can be understood that the Diniyah Conversion Taklim Council (MTKD) is a model of majelis taklim converted to the madarasah diniyah model, which was held on the initiative of the Head of the Office of the Ministry of Religion of Bandung City and then received support from the Bandung City Government. As for those who become the implementers are the Islamic religious extension agents. This was done to meet the needs of society in understanding Islamic religious knowledge.

Curriculum objectives form the basis of curriculum development and user orientation. There are two kinds of curriculum objectives, namely general goals and specific goals. The general objectives are set in a broader and richer context and still a more specific explanation can be made. This goal describes what will be achieved which is usually an explanation or operation of the mind contained in the goal of the upper level (which is similar to selgan) but it is still descriptive.

Theoretically, the purpose of compiling the curriculum of the Bandung City Diniyah Al-lkhlas Conversion Council curriculum is in accordance with what is mandated by the government in Law No. 20 of 2003 concerning the National Education System, article 3 which explains 
that national education functions to develop capabilities and shape the character and civilization of a nation with dignity in order to educate the nation's life, aiming at developing the potential of congregations / santri to become human beings who believe and believe in God The One and Only, have noble character, are healthy, knowledgeable, capable, creative, independent and become democratic and responsible citizens.

One of the goals of community-based curriculum development is also in accordance with what Rusman said in his book Curriculum Management that the relationship between educational institutions and the community needs to be managed productively so that people feel they belong to the educational institution. Thus, community involvement in curriculum management is intended to be able to understand, assist and control curriculum implementation, so that educational institutions are required to be cooperative and able to independently identify curriculum needs, assess curriculum, control and report curriculum sources and results both to the community and to the government.

The curriculum content formulation is based on each level according to the abilities and needs of the congregation / students. By referring to each level and the needs of the jama'ah / santri, then there is a separation of subject matter and a grouping consisting of 6 groups of subject areas in the hope that the curriculum can meet the needs of the jama'ah / santri is very relevant to the theory presented by Abd. Ghani said that among the general features of the curriculum in Islamic education are (Ghani, t.t.):

a) Accentuate religious and moral objectives on various purposes, content, methods and techniques that are religious in character;

b) The relative balance between curriculum contents from various aspects of science.

c) Be thorough in arranging the required subjects; and

d) The curriculum is arranged according to the talents and interests of the congregation I students.

Scientific knowledge and other forms of learning experiences that are presented as material for students to study, generally contain or consist of the following main aspects:

1. Theory, which is a set of interconnected constructs or concepts, definitions or prepositions, which presents a systematic opinion about symptoms by specifying the relationships between variables with the intention of explaining and predicting these symptoms.

2. Concept, which is an abstraction formed by organization and specificities. A concept is a short definition of a group of facts or symptoms.

3. Generalization, namely a general conclusion based on specific matters, derived from analysis, opinion, or evidence in research.

4. Principles, namely the main idea, the schematic patterns present in the material which develop the relationship between several concepts.

5. Facts, namely a number of specific information in material deemed important, consisting of terminology, people and places, and events. 
6. Terms, namely new and special vocabulary words introduced in the material.

7. Examples or illustrations, namely matters of information, or actions or processes that aim to clarify a description or opinion.

8. Definition, namely an explanation of the meaning or understanding of a thing / word in outline.

In general, the method used in the Bandung City Diniyah Conversion Council curriculum is centered on two methods. First, lecturing for cognitive lessons. Second, participatory for lessons that have psychomotor elements such as observation and practice. The use of this method is aimed at finding a balance between the congregation / students receiving knowledge and providing understanding of the learning process that is being followed.

Apart from the two methods mentioned above, direct methods are often used by teachers as a form of creativity to achieve a better quality of education in majelis taklim. Each teacher is given the freedom to choose and determine the learning method that is deemed appropriate to be applied according to the characteristics of the lesson, the abilities and needs of the congregation. Although the majority of teachers deliver subject matter using the lecture method, there are variations in other teaching methods such as discussions, quizzes and practice.

Method is a method used to implement plans that have been prepared in real activities so that the objectives that have been prepared are achieved optimally (Sanjaya, 2005. p. 147). This means that the method is used to realize the predetermined teaching and learning process.

According to Abdurrahman Ginting, the learning method can be interpreted as a unique way or pattern in utilizing various basic principles of education as well as various techniques and other related resources so that the learning process occurs in the learner (Ginting, 2008. p. 42).

In other words, the learning method is a presentation technique that is mastered by a teacher to present subject matter to students in the class either individually or in groups so that the subject matter can be absorbed, understood and utilized by students properly (Ahmadi \& Prastya, 2005. p. 52).

From the various forms of teaching methods used, it can be seen that the curriculum of the Diniyah Conversion Taklim Council (MTKD) tries to apply the theory presented by Sutrisno that the teaching method can apply the dual method (a double movement) (Sutrisno, 2006. p. 56). The first movement is in the form of awareness of the congregation / santri and the second movement is related to social functions in society. The Diniyah Conversion Taklim Council (MTKD) seeks to make congregations aware of the importance of learning as a provision to serve in society. To complement it all, thematic delivery of material adapted to 
the experience of the congregation is also applied. For example in fiqh lessons, for three years the congregation studied material themes which were directly related to reality in society.

In terms of learning strategies, in general the strategies made must lead to the congregation's understanding and mastery of the lessons that have been given. In this case, how the teacher can successfully complete the subject matter in each semester and the congregation / students succeed in absorbing the knowledge given during the learning process.

In this case motivation needs to be raised as an awareness of the importance of knowledge. The teacher is said to be successful if it is able to arouse the motivation to learn of the congregation / students, its form is to do interesting and not boring learning with various kinds of learning methods. The effort to generate self motivation is to understand various learning methods. The self motivation that is sought is by providing rewards (awards) to each congregation / santri who are considered to be outstanding. You can also hold a quiz on every lesson so that it raises motivation to be more serious in taking lessons. Self motivation must always be prepared in learning for both the cognitive, affective and psychomotor domains of the congregation / students. Therefore, learning should not only be directed at the cognitive realm but must also pay attention to the affective and psychomotic dimensions.

Some of the strategies formulated in learning at the Diniyah Conversion Taklim Council (MTKD) when linked to the existing material include the implementation of activity-based, congregational / santri-based and community teaching. The values contained in learning activities include speaking skills, mastery of the material and the ability to solve problems that will be encountered in the midst of society.

The form of activity-based teaching can be grouped into six activities:

a) Visual activities such as viewing video shows, viewing pictures, diagrams and listening as in recitation lessons.

b) Oral activities such as discussions and presentations and muhadharah.

c) Lecture listening activities

d) Writing activities such as writing lecture scripts, or writing recitation material.

e) Mental activities such as planning and analyzing.

f) Emotional activities such as daring presentations and delivering lectures in muhadlarah activities.

Jama'ah / santri-based teaching at the Diniyah Conversion Taklim Council (MTKD) includes:

a) Modular learning center, where the congregation learns the material modules that have been made by the teacher.

b) Based on the experience of the congregation in the midst of their community, each congregation is asked to reveal the problems that occur in their community so that 
other congregations will participate in the analysis so that a discussion occurs among the congregation.

c) Based on inquiry, this is intended to find problems that exist in society. For example looking for examples of problems that often occur in the law of warits, the congregation is asked to find examples of cases then the results are presented and discussed.

The learning media in the Diniyah Conversion Taklim Council are interrelated with one another. In general, the media is determined and prepared by the curriculum team. However, in practice, teachers are required to play an active role in providing teaching media.

The various learning strategies implemented by the Diniyah Conversion Taklim Council (MTKD) are very comprehensive from what was stated by Oemar Hamalik that there are several effective learning strategies, namely expority learning, inquiry teaching, interactive teaching and small discussions. Examples of applied expority learning are listening to listening to lectures on moral subject matter, presentations on family fiqh and writing activities such as writing recitation lessons after understanding the content of the material.

The form of inquiry learning is reflected in research activities in the field and reading actual issues related to jurisprudence. The results are presented and discussed. And interactive teaching is carried out in teaching and learning activities when the teacher provides the opportunity to the congregation / students to ask questions that are less clear from the material that has been presented or by asking questions to measure the level of children's understanding of the material.

From the various forms of teaching methods used, it can be seen that the curriculum of the Diniyah Conversion Taklim Council (MTKD) tries to apply the theory presented by Sutrisno that the teaching method can apply the dual method (a double movement) (Sutrisno, 2006. p. 56). The first movement is in the form of awareness of the congregation / santri and the second movement is related to social functions in society. The Diniyah Conversion Taklim Council (MTKD) seeks to make congregations aware of the importance of learning as a provision to serve in society. To complement it all, thematic delivery of material adapted to the experience of the congregation is also applied. For example in fiqh lessons, for three years the congregation studied material themes which were directly related to reality in society.

After undergoing an integral learning process, graduates of the Diniyah Conversion Council (MTKD) are expected to have attitudes, knowledge and skills that have been determined by the curriculum objectives.

From several research findings it can be understood that the Diniyah Conversion Council (MTKD) is a model of majelis taklim implemented with the Madrasah Diniyah system, so that 
the curriculum and learning activities run in a structured and systematic manner, which initially majelis taklim are generally managed traditionally without knowing the curriculum system. structured and systematic.

\section{CONCLUSION}

Planning for curriculum implementation is carried out by stages of compiling a curriculum that is tailored to the needs and level of knowledge of the congregation, then determining the concept of the curriculum to be applied, the methods to be used and the learning strategies to be implemented. The curriculum team compiles learning materials and divides learning materials into semester, monthly and material in each meeting.

\section{References :}

Ahmadi, A., \& Prastya, J. T. (2005). Strategi Belajar Mengajar. CV Pustaka Setia. Arifin, Z. (2013). Konsep dan Model Pengembangan Kurikulum. PT. Remaja Rosdakarya. Beane, J. A. (1986). Curriculum Planning and Development. Allyn and Bacon.

Fullan. (2007). School development: The new meaning of educational change. Teacher College Press.

Ghani, Abd. (t.t.). Hakikat Kurikulum Pendidikan Islam. Diambil 2 Maret 2020, dari http:/wordpress.com/hakikat-kurikulum-pendidikan-islam/

Ginting, A. (2008). Esensi Praktis Belajar dan Pembelajaran. Humaniora.

Hamalik, O. (2006). Manajemen Pengembangan Kurikulum. PT. Remaja Rosdakarya.

Hamalik, O. (2010). Kurikulum dan Pembelajaran. Bumi Aksara.

Nasution, S. (2010). Kurikulum dan Pengajaran. Bumi Aksara.

Olivia, P. F. (1992). Developing the Curriculum. Harpers Collin Publisher.

Ornstein, A. C., \& Francis, P. H. (2009). Curriculum: Foundations, Prinsiples, and Issues. Allyn \& Bacon.

Sagala, S. (2008). Sentuhan Pedagogis Dilakukan Dalam Pengembangan Kurikulum Mendukung Proses Pembelajaran Dalam Profesionalisme Pendidik Dan Tenaga Kependidikan Melalui Penerapan Teknologi Pendidikan. Unimed, IPTPL.

Sanjaya, W. (2005). Pembelajaran dalam Implementasi Kurikulum Berbasis Kompetensi. Kencana Prenada Media Group.

Sukmadinata, N. S. (2012). Pengembangan Kurikulum: Teori dan Praktek. Rosdakarya.

Sutrisno. (2006). Pendidikan Islam yang Menghidupkan; Studi Kritis terhadap Pemikiran Fazlur Rahman. Kota Kembang. 